\title{
Energy Efficiency and Environmental Analysis of the Green-Hydrogen Fueled Slow Speed Marine Diesel Engine
}

\author{
Nader R. Ammar ${ }^{1,2 *}$ \\ ${ }^{1}$ Department of Marine Engineering, Faculty of Maritime Studies, King Abdulaziz University, 21589 Jeddah, Saudi Arabia \\ ${ }^{2}$ Department of Naval Architecture and Marine Engineering, Faculty of Engineering, Alexandria University, 21544 Alexandria, Egypt \\ Received 15 Sept 2018, Accepted 20 Nov 2018, Available online 22 Nov 2018, Vol.6 (Nov/Dec 2018 issue)
}

\begin{abstract}
Marine diesel engines are facing challenges to cope with the emission-reduction regulations set by the international maritime organization (IMO). Hydrogen fuel is one of the alternative fuels which can be used to reduce the exhaust gas emissions from ships. The current paper investigates the effect of using diesel-hydrogen dual fuels on the environmental, energetic and exergetic performance parameters of slow speed marine diesel engine. The investigation is performed using Engineering Equation Solver (EES) software package. As a case study, slow speed diesel engine has been investigated. The results obtained revealed that the energetic and exergetic parameters are influenced by engine load and hydrogen substitution percent. The exergy efficiency is increased by $3.65 \%, 8.20 \%, 13.99 \%$, and $21.7 \%$ for the hydrogen substitution percentages of $10 \%, 20 \%, 30 \%$, and $40 \%$, respectively compared with the diesel engine at full load. Environmentally, $\mathrm{CO}$ and $\mathrm{CO}_{2}$ emissions are reduced and $\mathrm{NO}_{x}$ emissions are increased as the hydrogen energy content increases. Dual fuel engine with input hydrogen energy fractions of $10 \%$ and $20 \%$ will comply with the required $\mathrm{NO}_{x}$ emission regulations set by IMO after using selective catalytic reduction (SCR) system. It will comply with the required regulations with relative percentages of $96.4 \%$ and $98.4 \%$, respectively.
\end{abstract}

Keywords: Marine diesel engine, Hydrogen, Energy and exergy analysis, Environmental aspects.

\section{Introduction}

The need for alternative marine fuels is one of the most important requirements for marine diesel engines to cope with the stringent emission regulations set by the international maritime organization (IMO) [1-5]. In addition, the fast depletion of fossil fuels with their harmful environmental impacts encourages the need for renewable and clean alternative fuels [6-8]. Hydrogen fuel is one of the promising, renewable, and environmental friendly fuels for the future [9-12]. Hydrogen fuel has wide range of flammability limits, high heating value and stoichiometric air to fuel ratio and low specific gravity compared with diesel fuel as illustrated in Table 1 . With these characteristics, hydrogen fuel can be used solely or combined with other fuels to improve the combustion and consequently reduce the exhaust gas emissions [13, 14]. Hydrogen fuel was proposed for spark ignition (SI) engines in many researches since 1970. The main problems associated with these applications are the reduced output power, knocking, and backfire, especially at high engine loads due to the combustion

*Corresponding author's ORCID ID: 0000-0002-1976-7274 DOI: https://doi.org/10.14741/ijmcr/v.6.6.10 characteristics of hydrogen fuel [15-18]. Thus, hydrogen application in $\mathrm{SI}$ engines is limited to well-defined operating conditions [19]. On the other hand, hydrogen fuel is not currently economically feasible compared with fossil fuels due to its high cost and the lake of the infrastructure [15]. In addition to that, the relatively high auto-ignition temperature of the hydrogen fue recommended it to operate with diesel fuel in dual fuel mode engine in order to reduce exhaust and greenhouse gases emissions [20].

Table 1 Diesel fuel and hydrogen fuels properties [21-25]

\begin{tabular}{ccc}
\hline Properties & Diesel fuel & Hydrogen gas \\
\hline Density at 160 C and 1.01 bar & $833-881$ & 0.0838 \\
Molecular weight (g/mole) & 100 & 2 \\
Auto ignition temperature (K) & 530 & 858 \\
Flammability limits (volume \% & $0.7-5$ & $4-75$ \\
in air) & 14.5 & 34.3 \\
Stoichiometric air-fuel ratio on & & \\
mass basis & 41.8 & 119.93 \\
Net lower heating value & 30 & $265-325$ \\
(MJ/kg) & 30 & 130 \\
Flame velocity (cm/s) & $436-672$ & $20-27$ \\
Octane number & 0.83 & 0.091 \\
Boiling point (K) & & \\
Specific gravity &
\end{tabular}

1347|Int. J. of Multidisciplinary and Current research, Vol.6 (Nov/Dec 2018) 
The performance of the diesel-hydrogen dual fuel engine (DFE) for a single cylinder diesel engine was carried out by [26]. They reported that the brake thermal efficiency increased by $3.2 \%$ using $12.5 \%$ of the supplied energy by hydrogen gas, at engine full load. The enhanced brake thermal efficiency was a result of the improved combustion efficiency. The performance and emissions of compression ignition $(\mathrm{Cl})$ engine fueled with hydrogen enriched diesel are simulated by [27] with numerical simulation using LOTUS Code. They concluded that high air to fuel ratios with $30 \%-40 \%$ hydrogen percentages results in maximizing the engine power. Nguyen et al.[28] studied experimentally the effect of hydrogen addition on four stroke diesel engine noise at a compression ratio of 16.7. Results indicated that the noise level is reduced at $10 \%$ hydrogen addition (on volumetric basis). The experimental analysis of adding hydrogen $\left(\mathrm{H}_{2}\right)$ and liquefied petroleum gas (LPG) on dual fuel four-stroke diesel engine efficiency and pollution was carried out by [29] reported that knocking in dual fuel engine appeared when $50 \% \mathrm{H}_{2}$ [21] and 70\% LPG is adding alone. Using $30 \% \mathrm{H}_{2}$ and $40 \%$ LPG in dual fuel engine modes, the thermal efficiency increased to $17 \%$ and $6 \%$, respectively. Pan et al. [20] tested two-stroke marine diesel engine mounted on a dynamometer at three loads specified in the ISO 8178-4 E3 emission test cycle and at idle. The engine is operated with ultra-low sulfur diesel oil with hydrogen added at flow rates of 0, 22 and 220 SLPM. The results show that specific reductions in $\mathrm{CO}, \mathrm{CO} 2$, unburned hydrocarbon (UHC) emissions with increased $\mathrm{NO}_{\mathrm{x}}$ emissions. The performance of DFE for a single cylinder diesel engine using different ranges of hydrogen fractions and injection timing was studied by [30]. They suggested preferable injection-timing methods to reduce smoke and $\mathrm{NO}_{x}$ emissions. Another method reported by [31] to reduce $\mathrm{NO}_{x}$ emission using supercharging in addition to controlling fuel injection timing.

Although the majority of the researches about the application of hydrogen fuel are land based applications, it can also be a good option for marine applications [11, 32]. Veldhuis et al. [33] investigated the potential for hydrogen fuel in the marine environment from infrastructure, technical, and economical points of view for the design of high speed catamaran ship. The results show that the vessel is technically feasible and it depends on the availability of hydrogen transport chain and cost. Slow speed diesel engines are the major source for exhaust gas emissions from ships [34, 35]. Therefore, the aim of the current paper is to investigate the effect of using hydrogen gas in marine diesel engines, in dual mode of operation, on the energy and the exergy points of view. As a case study, slow speed marine diesel engine of a container vessel is investigated. In addition, the environmental analysis is included for the dual fue engine and the $\mathrm{NO}_{\mathrm{x}}$ emission rates are compared with the permissible IMO limits.

\section{Case study}

Table 2 Shop test result for the Al Dhail container ship main engine (Hyundai LTD)

\begin{tabular}{|c|c|c|c|c|c|c|c|}
\hline Engine power $(\mathrm{kW})$ & 9405 & 18810 & 22572 & 28215 & 32617 & 33858 & 37620 \\
\hline Load (\%) & 25 & 50 & 60 & 75 & 86.7 & 90 & 100 \\
\hline Speed (rpm) & 45.4 & 57.1 & 60.7 & 65.4 & 68.7 & 69.5 & 72.0 \\
\hline $\mathrm{P}_{\max .}$ (bar) & 96 & 129 & 144 & 163 & 185 & 186 & 184 \\
\hline $\mathrm{P}_{\text {comp. }}$ (bar) & 61.4 & 88.4 & 100.9 & 122.3 & 144.8 & 145.5 & 147.7 \\
\hline $\mathrm{SFC}(\mathrm{g} / \mathrm{kWh})$ & 189.6 & 175 & 171.7 & 169.2 & 169.2 & 169.5 & 171.5 \\
\hline$\dot{m}_{\text {air }}(\mathrm{kg} / \mathrm{s})$ & 22.25 & 23.98 & 25.92 & 28.87 & 30.56 & 30.88 & 31.39 \\
\hline$\dot{m}_{j c w}(\mathrm{~kg} / \mathrm{s})$ & 18.48 & 31.1 & 36.31 & 44 & 49.8 & 51.44 & 56.78 \\
\hline$\dot{m}_{\text {liuboil }}(\mathrm{kg} / \mathrm{s})$ & 30.76 & 56.54 & 66.56 & 81.94 & 94.69 & 98.47 & 110.6 \\
\hline$\dot{m}_{\text {exh }}(\mathrm{kg} / \mathrm{s})$ & 22.74 & 24.89 & 27 & 30.2 & 32.09 & 32.47 & 33.18 \\
\hline $\mathrm{T}_{\text {exh, turb,in }}(\mathrm{K})$ & 547 & 694 & 718 & 759 & 802 & 815 & 850 \\
\hline $\mathrm{T}_{\text {exh, turb,out }}(\mathrm{K})$ & 485 & 583 & 603 & 627 & 648 & 655 & 680 \\
\hline
\end{tabular}

The engine under study is the main propulsion engine for the Al Dhail container ship with IMO number of 9732307. The ship was built in 2016 with a registered port of Marshall Islands. Her deadweight is 149, 360 ton. The main engine type is Hyundai-MAN B\&W 9590 ME-C 10.2. Its maximum continuous rating (MCR) power is 37,620 $\mathrm{kW}$ at $72 \mathrm{RPM}$. The engine operates with ultra-low sulfur marine fuel oil (ULSFO) with $0.1 \% \mathrm{~S}$. Table 2 shows the main shop-test performance parameters of the main engine at part load. The data presented in Table 2 is provided by the engine maker company (Hyundai LTD.) in the engine project guide and shop test results. The experimental data provided in the main engine shop tests are accredited by the Det Norske Veritas (DNV) and
Germanischer Lloyd (GL) classification societies. The tests performed at ISO conditions and the specific fuel oil consumptions (SFC) are corrected to the Lower Calorific Value (LCV) of $41838.93 \mathrm{~kJ} / \mathrm{kg}$.

For the purpose of energy modeling, the relation between main engine performance parameters should be identified using shop test results. For example, Figures 1 and 2 show the specific fuel consumption and exhaust gases temperature correlations at different main engine part loads, respectively. It can be noted that, as the engine load increases, the exhaust gases temperature increase with the reduced specific fuel oil consumption. The correlations are generated using polynomial curve fitting method. They will be used to establish the energy 
and exergy balance sheets for the main engine. In addition, they are used to study the effect of dieselhydrogen dual fuels for the main engine from energy, exergy and environmental points of view.

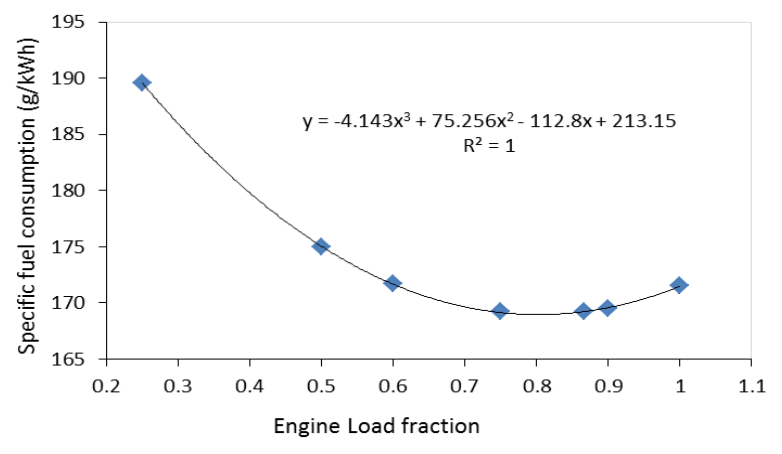

Figure 1 Correlations of the main engines specific fuel consumption

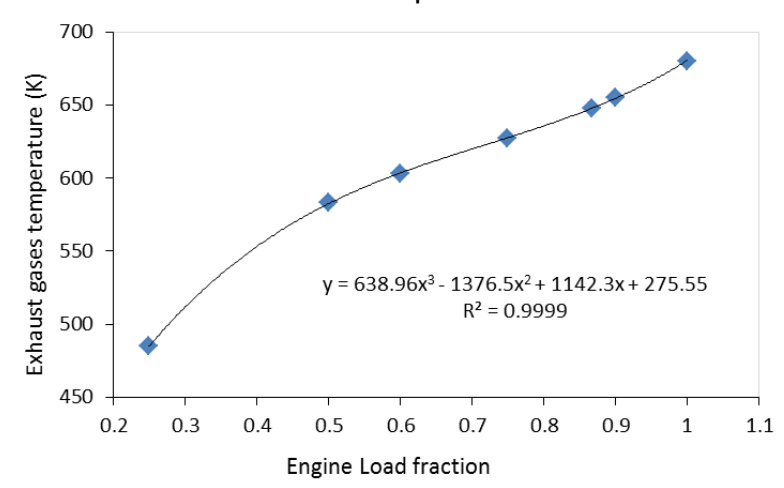

Figure 2 Exhaust gases temperature correlations

\subsection{Energy and exergy modeling}

Marine diesel engine can be represented by a control volume with inlet air and fuel flows and output useful power in addition to the different waste heat losses as shown in Figure 3. The main assumptions for energy and exergy analysis are steady state condition, ideal gases, and ignored potential and kinetic exergies.

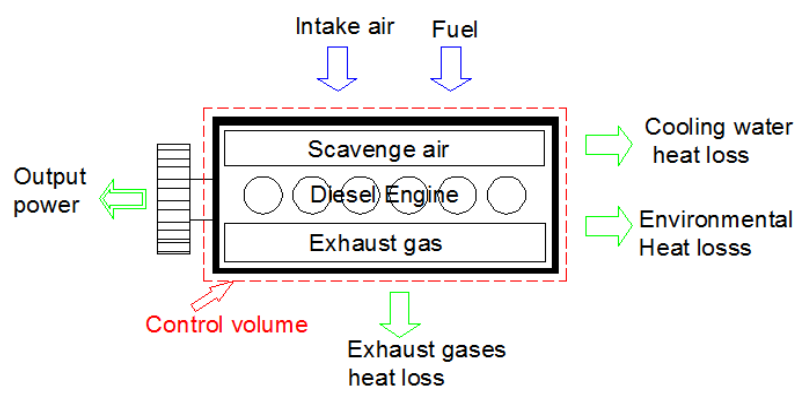

Figure 3 Marine diesel engine control volume showing input and output exergy flows

The brake thermal efficiency $\left(\eta_{b t h}\right)$ of the diesel engine control volume can be expressed as:
$\eta_{\mathrm{bth}}=\frac{\dot{\mathrm{Q}}_{\mathrm{o}}}{\dot{\mathrm{Q}}_{\mathrm{f}}+\dot{\mathrm{Q}}_{\mathrm{a}}}$

where $\dot{\mathrm{Q}}_{\mathrm{o}}$ is the output shaft power in $\mathrm{kW}, \dot{\mathrm{Q}}_{\mathrm{f}}$ and $\dot{\mathrm{Q}}_{\mathrm{a}}$ are the energy added by the fuel and air, respectively as expressed in the following Eqs. 2 and 3.

The energy added by the fuel $\left(\dot{Q}_{f}\right)$ can be calculated as a function of the fuel mass flow rate $\left(\dot{m}_{f}\right)$ in $\mathrm{kg} / \mathrm{s}$ and the lower heating value of the used fuel (LHV) in $\mathrm{kJ} / \mathrm{kg}$ as shown in Eq. 2.

$\dot{\mathrm{Q}}_{\mathrm{f}}=\dot{\mathrm{m}}_{\mathrm{fd}} \mathrm{LHV}_{d}+\dot{\mathrm{m}}_{\mathrm{fH}_{2}} \mathrm{LHV}_{\mathrm{H}_{2}}$

The input air energy $\left(\dot{Q}_{\text {air }}\right)$ is calculated using Eq. 3.

$\dot{\mathrm{Q}}_{\mathrm{a}}=\dot{\mathrm{m}}_{\mathrm{a}} \mathrm{C}_{\mathrm{p}, \mathrm{a}}\left(\mathrm{T}_{\mathrm{a}}-\mathrm{T}_{0}\right)$

where $m_{a}, C_{p, a}, T_{a}$, and $T_{0}$ are the air mass flow rate in $\mathrm{kg} / \mathrm{s}$, specific heat capacity in $\mathrm{kJ} / \mathrm{kg} . \mathrm{K}$, inlet air temperature, and the dead state temperature $\left(10^{\circ} \mathrm{C}\right)$.

$\mathrm{C}_{\mathrm{p}, \mathrm{a}}$ can be calculated as a function of $\mathrm{T}_{\mathrm{a}}$ in $(\mathrm{K})$ using the following equation [36].

$$
\begin{aligned}
\mathrm{C}_{\mathrm{pa}}=1.04841- & 0.0003837 \mathrm{~T}_{\mathrm{a}}+\frac{9.45378 \mathrm{~T}_{\mathrm{a}}{ }^{2}}{10^{7}} \\
- & \frac{5.49031 \mathrm{~T}_{\mathrm{a}}{ }^{2}}{10^{10}}+\frac{7.92981 \mathrm{~T}_{\mathrm{a}}{ }^{2}}{10^{14}}
\end{aligned}
$$

In addition, the exergy efficiency $(\Psi)$ of the diesel engine can be calculated as follows:

$\Psi=\frac{\dot{E}_{o}}{\dot{E}_{f}+\dot{E}_{a}}$

where $\dot{\mathrm{E}}_{\mathrm{o}}, \dot{\mathrm{E}}_{\mathrm{f}}$ and $\dot{\mathrm{E}}_{\mathrm{a}}$ are the exergy flow rates of the output shaft work, fuel, and air, respectively.

Exergy efficiency contributes to the sustainable developments of diesel engine $[37,38]$, which is directly related to the sustainability index $\left(\mathrm{S}_{\mathrm{i}}\right)$, as shown in Eq. 6 .

$\Psi=1-\frac{1}{S_{i}}$

The output shaft work exergy flow rate is equal to the output shaft work (Eq. 7). It is a function of the shaft angular velocity $(\omega)$ and the generated torque (T) [39].

$\dot{\mathrm{E}}_{\mathrm{o}}=\dot{\mathrm{Q}}_{o}=\omega \mathrm{T}$

Taking into account the chemical exergy only, the exergy flow rate of the combustion fuel $\left(\dot{\mathrm{E}}_{\mathrm{f}}\right)$ can be calculated using Eq. 8 [40].

$\dot{\mathrm{E}}_{\mathrm{f}}=\dot{\mathrm{m}}_{\mathrm{f}} \cdot \mathrm{e}_{\mathrm{LHV}} \cdot \mathrm{LHV}$

where LHV is the combustion fuel lower heating value. $\mathrm{e}_{\mathrm{LHV}}$ is the fuel chemical exergy factor. It is a function of 
the mass fraction of carbon $(\mathrm{C})$, hydrogen $(\mathrm{H})$, oxygen $(\mathrm{O})$, and sulfur (s) in the combustion fuel, as expressed using Eq. 9 [41].

$$
\begin{aligned}
\mathrm{e}_{\mathrm{LHV}}=1.0401+ & 0.1728\left(\frac{\mathrm{H}}{\mathrm{C}}\right)+0.0432\left(\frac{\mathrm{O}}{\mathrm{C}}\right) \\
& +0.2169\left(\frac{\mathrm{S}}{\mathrm{C}}\right) \\
& \times\left(1-2.0268\left(\frac{\mathrm{H}}{\mathrm{C}}\right)\right)
\end{aligned}
$$

Table 3 presents the Stoichiometric air to fuel ratio, density and fuel chemical exergy factor of the simulated dual fuels $[39,42]$.

Table 3 Fuel properties used in dual marine diesel engine simulation

\begin{tabular}{ccccc}
\hline Fuel type & $\begin{array}{c}\text { Stoichiometric } \\
\mathrm{A} / \mathrm{F} \mathrm{ratio}\end{array}$ & $\begin{array}{c}\text { Density } \\
\left(\mathrm{kg} / \mathrm{m}^{3}\right)\end{array}$ & $\begin{array}{c}\mathrm{CV}_{\text {LHV }} \\
(\mathrm{kJ} / \mathrm{kg})\end{array}$ & $\mathrm{e}_{\text {LHV }}(\mathrm{kJ} / \mathrm{kg})$ \\
\hline $\begin{array}{c}\text { Diesel } \\
\begin{array}{c}\text { Hydrogen } \\
\left(\mathrm{H}_{2}\right)\end{array}\end{array}$ & 14.5 & $800-845$ & $41,838.93$ & $44,582.79$ \\
\hline
\end{tabular}

The inlet air to the diesel engine exergy flow rate $\left(\dot{E}_{\mathrm{a}}\right)$ can be expressed as follows:

$$
\begin{array}{r}
\dot{\mathrm{E}}_{\mathrm{a}}=\dot{\mathrm{m}}_{\mathrm{a}}\left[\mathrm{C}_{\mathrm{p}, \mathrm{a}}\left(\mathrm{T}_{\mathrm{a}}-\mathrm{T}_{0}-\mathrm{T}_{0} \ln \left(\frac{\mathrm{T}_{\mathrm{a}}}{\mathrm{T}_{0}}\right)\right)\right. \\
\left.+\mathrm{RT}_{0} \ln \left(\frac{\mathrm{P}_{\mathrm{a}}}{\mathrm{P}_{0}}\right)\right]
\end{array}
$$

where $P_{a}, R$ are the pressure of the intake air and the gas constant $(0.287 \mathrm{~kJ} / \mathrm{kg} \mathrm{K})$, respectively, $P_{0}$ and $T_{0}$ are the dead state pressure and temperature $(101.315 \mathrm{kPa}$ and10 $\left.{ }^{\circ} \mathrm{C}\right)$.

The heat lost with the exhaust gases can be expressed as a function of the average specific heat capacity $\left(C_{p, e x h}\right)$ and temperature $\left(T_{\text {exh }}\right)$ of the exhaust hot gases as expressed in Eq. $11[43,44]$.

$\dot{\mathrm{Q}}_{\mathrm{exh}}=\left(\dot{\mathrm{m}}_{\mathrm{a}}+\dot{\mathrm{m}}_{\mathrm{f}}\right) \mathrm{C}_{\mathrm{p}, \mathrm{exh}}\left(\mathrm{T}_{\mathrm{exh}}-\mathrm{T}_{0}\right)$

The exhaust hot gas exergy flow rate is the summation of its chemical ( $\left.\dot{\mathrm{E}}_{\text {exh,ch }}\right)$ and physical exergy $\left(\dot{\mathrm{E}}_{\text {exh,ph }}\right)$ flow rates as follows [41]:

$$
\dot{\mathrm{E}}_{\mathrm{exh}}=\dot{\mathrm{E}}_{\mathrm{exh}, \mathrm{ph}}+\dot{\mathrm{E}}_{\mathrm{exh}, \mathrm{ch}}
$$

The exhaust hot gas physical exergy flow rate can be calculated using the following equation [41]:

$$
\begin{aligned}
\dot{\mathrm{E}}_{\text {exh,ph }}=\left(\dot{\mathrm{m}}_{\mathrm{a}}+\right. & \left.\dot{\mathrm{m}}_{\mathrm{f}}\right)\left[\mathrm { C } _ { \mathrm { p } , \mathrm { exh } } \left(\mathrm{T}_{\text {exh }}-\mathrm{T}_{0}\right.\right. \\
& \left.\left.-\mathrm{T}_{0} \ln \left(\frac{\mathrm{T}_{\text {exh }}}{\mathrm{T}_{0}}\right)\right)+\mathrm{RT}_{0} \ln \left(\frac{\mathrm{P}_{\text {exh }}}{\mathrm{P}_{0}}\right)\right]
\end{aligned}
$$

where $P_{\text {exh }}$ is the exhaust gases pressure and $C_{p \text {,exh }}$ is the summation of the mass fraction $\left(Y_{i}\right)$ and specific heat capacity $\left(C_{p, i}\right)$ of exhaust hot gas components (i) as expressed in Eq. 14.

$\mathrm{C}_{\mathrm{p}, \mathrm{exh}}=\sum_{\mathrm{i}} \mathrm{Y}_{\mathrm{i}} \mathrm{C}_{\mathrm{p}, \mathrm{i}}$

In addition, the exhaust gases chemical exergy can be calculated using the following equation [45]:

$$
\begin{aligned}
\dot{\mathrm{E}}_{\mathrm{exh}, \mathrm{ch}}=\left(\dot{\mathrm{m}}_{\mathrm{a}}+\dot{\mathrm{m}}_{\mathrm{f}}\right) \mathrm{n}\left(\sum_{\mathrm{i}} \mathrm{x}_{\mathrm{i}} \mathrm{e}_{\mathrm{i}}\right. \\
\left.+\mathrm{R}_{1} \mathrm{~T}_{0} \sum_{\mathrm{i}} \mathrm{x}_{\mathrm{i}} \ln \left(\mathrm{x}_{\mathrm{i}}\right)\right)
\end{aligned}
$$

where $\mathrm{n}$ is the number of moles per kilogram of exhaust gases, $x_{i}, e_{i}$ are the molar fraction and the standard chemical exergy in $\mathrm{kJ} / \mathrm{mole}$ of each exhaust gas component, and $\mathrm{R}_{1}$ is the universal gas constant per mol $(0.008314 \mathrm{~kJ} / \mathrm{mol} \mathrm{K})$. The different values of $e_{i}$ and $C_{p}$ of the exhaust gas species are calculated using EES program and the results are validated by the references $[36,46$, 47].

The heat rate transferred to the sea water coolers of the diesel engine $\left(\dot{Q}_{\mathrm{cw}}\right)$ can be calculated using Eq. 16 [48]. It is the summation of the engine jacket $\left(\dot{Q}_{j c w}\right)$, charge (inlet) air $\left(\dot{Q}_{c h . a, c w}\right)$, lubricating oil $\left(\dot{Q}_{\text {lub.oil }}\right)$ coolers heat.

$$
\begin{array}{r}
\dot{\mathrm{Q}}_{\mathrm{cw}}=\dot{Q}_{j c w}+\dot{Q}_{\text {lub.oil }}+\dot{Q}_{\text {ch.a,cw }} \\
=\dot{\mathrm{m}}_{\mathrm{w}} \mathrm{C}_{\mathrm{w}}\left(\mathrm{T}_{\mathrm{w}, \mathrm{o}}-\mathrm{T}_{\mathrm{w}, \mathrm{i}}\right)
\end{array}
$$

where $\dot{\mathrm{m}}_{\mathrm{w}}, \mathrm{C}_{\mathrm{w}}, \mathrm{T}_{\mathrm{w}, \mathrm{o}}$, and $\mathrm{T}_{\mathrm{w}, \mathrm{i}}$ are the mass flow rate, specific heat capacity $(4.18 \mathrm{~kJ} / \mathrm{kg} \mathrm{K})$, outlet and inlet temperatures of the cooling water.

In addition, diesel engine cooling water exergy loss rate $\left(\dot{\mathrm{E}}_{\mathrm{cw}}\right)$ can be computed as:

$\dot{\mathrm{E}}_{\mathrm{cw}}=\dot{\mathrm{m}}_{\mathrm{cw}} \mathrm{C}_{\mathrm{p}, \mathrm{w}}\left[\mathrm{T}_{\mathrm{w}, \mathrm{o}}-\mathrm{T}_{\mathrm{w}, \mathrm{i}}-\mathrm{T}_{0} \ln \left(\frac{\mathrm{T}_{\mathrm{w}, \mathrm{o}}}{\mathrm{T}_{\mathrm{w}, \mathrm{i}}}\right)\right]$

The heat loss to the environment $\left(\dot{Q}_{\text {env }}\right)$ from diesel engine can be calculated using the difference between total inputs and outputs energies as expressed in the following equation:

$\dot{Q}_{e n v}=\left(\dot{Q}_{a d d}+\dot{Q}_{a i r}\right)-\left(\dot{Q}_{o}+\dot{Q}_{e x h}+\dot{Q}_{c w}\right)$

The exergy loss rate of the heat transfer to the environment can be assessed as a function of the diesel engine working environment temperature ( $\left.T_{\text {env }}\right)$ as follows: 
$\dot{E}_{e n v}=\dot{Q}_{e n v}\left(1-\frac{T_{0}}{T_{e n v}}\right)$

Finally, the amount of the destructed exergy due to system irreversibility can be calculated using the exergy balance equation for the diesel engine control volume which can be expressed as:

$\dot{\mathrm{E}}_{\text {dest }}=\left(\dot{\mathrm{E}}_{\mathrm{a}}+\dot{\mathrm{E}}_{\mathrm{f}}\right)-\left(\dot{\mathrm{E}}_{\mathrm{exh}}+\dot{\mathrm{E}}_{\mathrm{o}}+\dot{\mathrm{E}}_{\mathrm{cw}}+\dot{\mathrm{E}}_{\mathrm{env}}\right)$

From environmental point of view, the emission quantity per trip for the ship $\left(m_{e m, t r i p}\right)$ can be computed using the following equation:

$\mathrm{m}_{\mathrm{em} \text {,trip }}=\sum \mathrm{T} \cdot \mathrm{P}_{\mathrm{i}, \mathrm{j}} \cdot \mathrm{L}_{\mathrm{i}, \mathrm{j}} \cdot \mathrm{F}_{\mathrm{i}, \mathrm{j}}$

where, $T, P$, and $L$ are the engine running time, output power, and load. $F$ is the emission factor for the combusted fuel in $\mathrm{kg} / \mathrm{kWh}$, $\mathrm{i}$ and $\mathrm{j}$ are the pollutant and fuel types.

For dual diesel and hydrogen fuels, the emission factor for the dual hydrogen engine $\left(F_{D H E}\right)$ can be calculated using Eq. 22.

$\mathrm{F}_{\mathrm{DHF}}=\mathrm{F}_{\mathrm{DE}}+\left(\mathrm{X}_{\mathrm{H}_{2}} \cdot \mathrm{F}_{\mathrm{HE}}\right)$

where $F_{D E}$ and $F_{H E}$ are the emission factor for the diesel and the hydrogen engines, respectively. $X_{H 2}$ is the hydrogen percent in hydrogen-diesel dual fuel engine. The emission factor for slow speed marine diesel engine firing ultra-low sulfur fuel $(0.1 \% \mathrm{~S})$ are $17 \mathrm{~g} / \mathrm{kWh}, 588.79$ $\mathrm{g} / \mathrm{kWh}, 1.4 \mathrm{~g} / \mathrm{kWh}, 0.5 \mathrm{~g} / \mathrm{kWh}$ for nitrogen oxides $\left(\mathrm{NO}_{\mathrm{x}}\right)$, carbon dioxide $\left(\mathrm{CO}_{2}\right)$, carbon monoxide (CO), hydrocarbon (HC) emissions, respectively [49].

\section{Results and discussion}

In this section, the energy, exergy and environmental results of the diesel-hydrogen dual fuel engine are presented. Energy and exergy results are based on the fraction of each component calculated by dividing its individual value to the air plus fuel input values. In addition to the energy and exergy assumptions included in the section 2.1, the results of the diesel and dual fuel engines are calculated at the same output power. Engineering Equation Solver (EES) software package is used to solve the energy and exergy equations.

\subsection{Energy analysis results}

The movement of energy flows in and out of marine diesel engines is an important factor in studying its performance. Using these flows, energy balances and efficiency can be easily determined which play an important role in the economic decisions for marine power plants selection. Sankey diagram is one of the visual energy flow balance representing tools. Figure 4 shows the Sankey diagram of the case study ship main engine energy flows. The chemical energy in the supplied marine fuel is converted in diesel engine in to usefu output mechanical energy to operate ship propeller and thermal energy losses. In addition, Figure 5 shows the energy flow balance of diesel and dual fuel engines using different hydrogen fuel percentages ranges from $10 \%$ to $40 \%$. It can be noted that the brake thermal efficiency increases with the increased hydrogen substitution percent due to the improved combustion efficiency of the mixture hydrogen and diesel fuels.

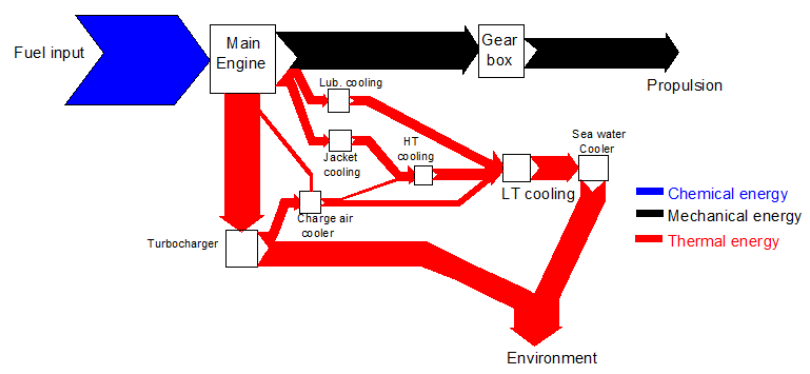

Figure 4 Sankey diagram of Al Dhail container ship main engine energy flows

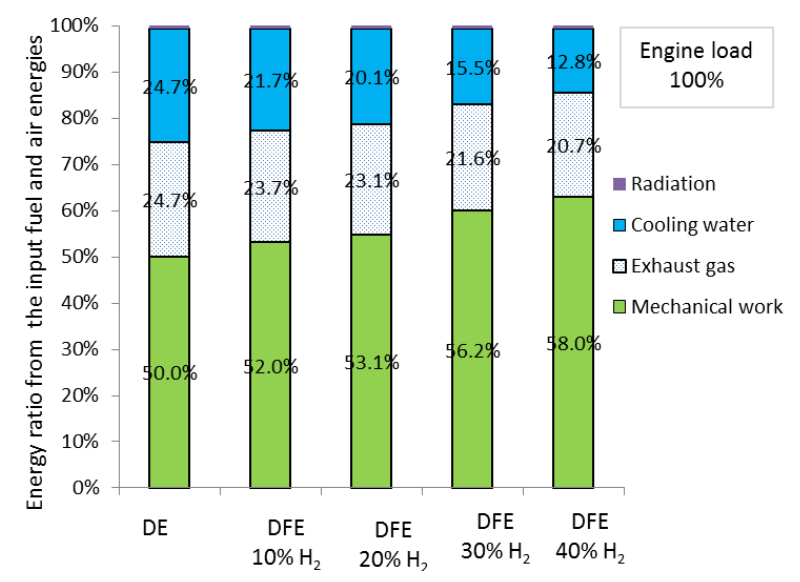

Figure 5 Energy balance of DE and DFE at full load using different hydrogen substitution percentages

The percentages of each energy component of the diesel energy balance diagram will be changed when using dual hydrogen-diesel fuels. Hydrogen substitution percentages in the current study is assumed to be increased up to $40 \%$ to prevent engine knocking problems occurred at high hydrogen percentages above $50 \%[21, \underline{29}]$. Figure 6 shows the effects of hydrogen fuel substitution percentages and engine load on brake thermal efficiency of the dual fuel engine. Brake thermal efficiency of the marine diesel engine increases with increasing the engine load fraction except at full load (72 rpm). This is because of the improved fuel energy magnitude converted to brake power which subsequently increases the engine brake thermal efficiency, at increased engine load for different 
hydrogen substitution percentages. However, brake thermal efficiency is reduced at engine full load due to the increased fuel consumption and the inverse relation between fuel consumption and the brake thermal efficiency Eq. 1.

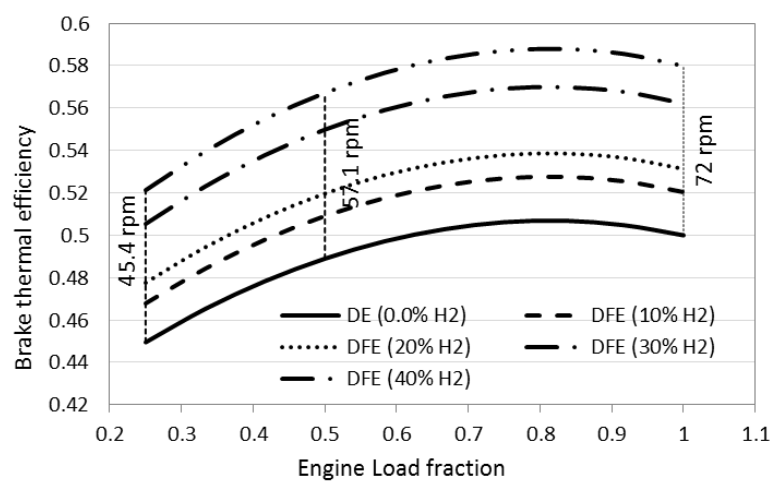

Figure 6 Dual fuel diesel engine brake thermal efficiency at part loads

Exhaust gases heat losses are the major heat loss source from marine diesel engine. Figure 7 shows the effect of substitution of hydrogen gas percentages in dual fuel engines on the exhaust gases temperature at three engine loads. All dual fuel engines with the different hydrogen substitution percentages have higher exhaust gases temperature than diesel engine at all engine loads. This is because of the increased engine efficiency when adding hydrogen gas to the diesel engines as a result of improved combustion efficiency due to favorable hydrogen gas flammable properties as shown in Table 1. In addition, the higher the main engine loads the higher the exit exhaust temperature as a result of the increased fuel consumption at high loads as illustrated in Figure 1.

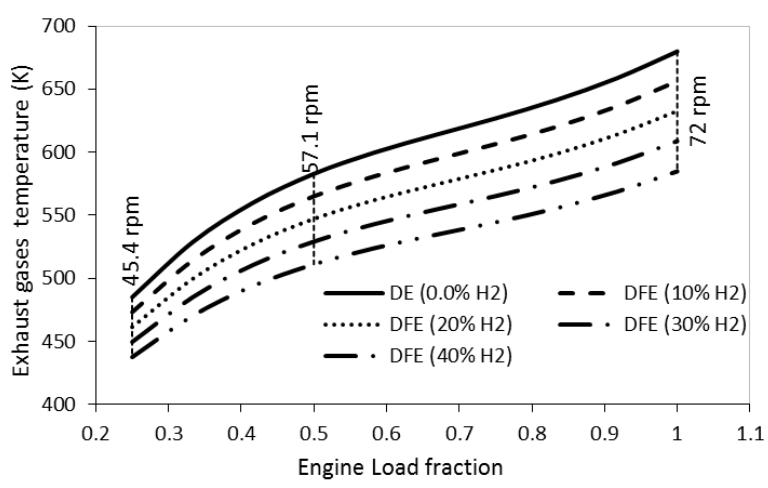

Figure 7 Effect of diesel and dual fuel engines loads on the exhaust gases temperature different hydrogen percentages

\subsection{Exergy analysis results}

Exergy balance of marine diesel engine helps in improving its performance through identifying the type and magnitude of the available energy fractions in the lost energy flows that can be used by one of the waste heat recovery systems. The exergy balance for the case study engine at full load is shown in Figure 8 using hydrogen substitution percentages ranges from $10 \%$ to $40 \%$. The exergy ratio of each component is calculated by dividing each exergy value by the summation of the input fuel and air exergies. Exergy destructed due to the processes irreversibility (like mechanical friction, heat transfer, mixing, and combustion) is the highest fraction of the lost exergies shown in Figure 8. It is reduced from $39.1 \%$ for the diesel engine to $37.2 \%, 34.6 \%, 31.7 \%$, and $27.6 \%$ for dual fuel engine with hydrogen percentages of $10 \%, 20 \%$, $30 \%$, and $40 \%$, respectively. Exhaust gases and cooling water exergy ratios have the next effective contributions in the lost exergies, respectively. These lost energy sources can be further used to produce a useful energy to increase the exergetic efficiency of the diesel engine. The highest exergy ratio for the studied diesel and dual fuel engines in all cases is the mechanical shaft work. A comparison between Figures 5 and 12 reveals that the input fuel exergy efficiency value is higher than its corresponding energy efficiency value since the quality or the exergy of the fuel is higher than its heating or energy value.

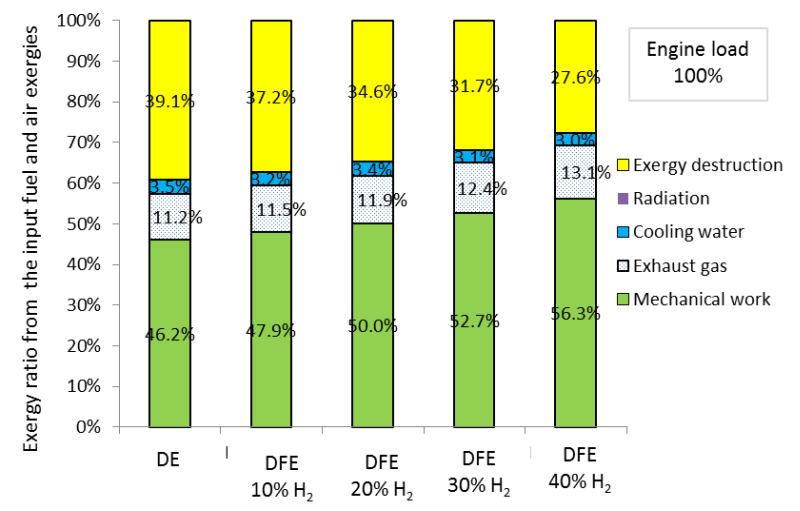

Figure 8 Exergy balance of DE and DFE at full load using different hydrogen substitution percentages

The exergy efficiency of the DFE depends on the engine load and hydrogen substitution percent as shown in Figure 9. Exergy and thermal efficiencies of the diesel engine have the similar trend but with alternative values. As the engine load increases, its exergy efficiency will be improved due to the efficient convergence of the supplied fuel to mechanical shat work (Eq. 5). The engine exergy efficiency is improved by increasing the hydrogen percent in dual hydrogen-diesel engine as a result of the better combustion efficiency of the diesel hydrogen fuels. The exergy efficiency of the DE and DFE ranges from $40 \%$ to $56 \%$ for the investigated hydrogen percentages from $10 \%$ to $40 \%$. At full engine load the exergy efficiency increased from $46.2 \%$ to $47.9 \%, 50 \%, 52.7 \%$, and $56.2 \%$ for the DFE with hydrogen substitution percentages of $10 \%, 20 \%, 30 \%$, and $40 \%$, respectively. 


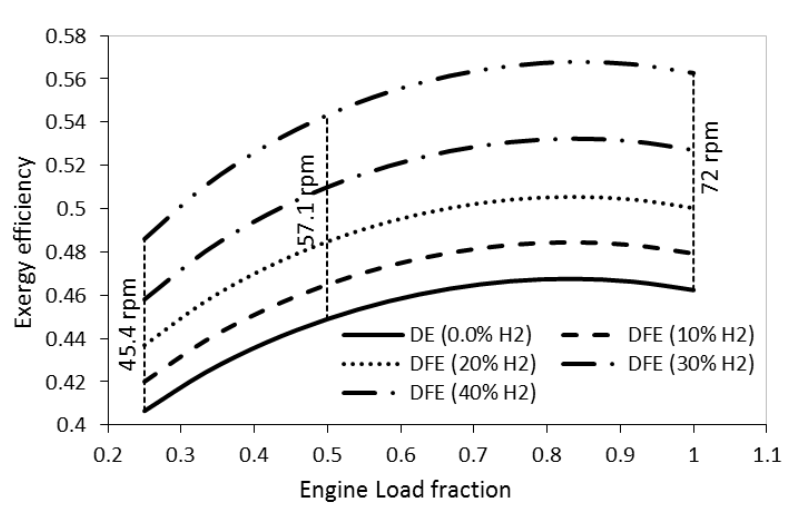

Figure 9 Exergy efficiency of the DE and DFE as a function of hydrogen fuel percent at different engine loads

Exergy efficiency and the sustainability index of the diesel engine are in direct relation as expressed in Eq. 6. It takes into account the effect of the first and the second laws of the thermodynamics to study the renewability and sustainability of the energy conversion in diesel engines. The higher the sustainability index value of the diesel engine, the lower its environmental impact. Fortunately, using dual hydrogen-diesel fuel engine improves the sustainability index values of the diesel engine as shown in Figure 10. The diesel engine sustainability index values range from 1.7 to 1.8 for engine load percentages of $25 \%$ and $100 \%$, respectively. These values are ranged from 1.9 to 2.2 , respectively using DFE with $40 \%$ hydrogen substitution percent.

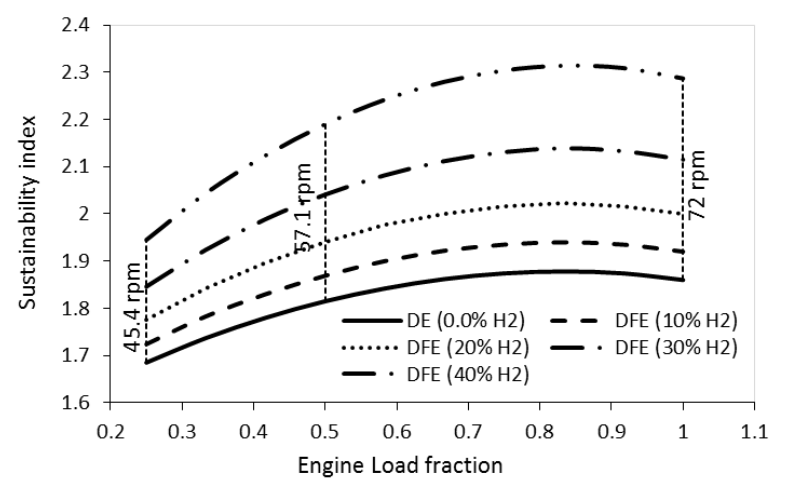

Figure 10 Effect of the DE and the DFE load fractions of the sustainability index

The second highest exergy loss source in diesel engine exergy balance Eq. 21 is the exhaust gases. The effect of DE and DFE load fractions on the exhaust gases exergy efficiency is shown in Figure 11. For the same output power of DE and DFE, the fuel consumption of DFE will be reduced and consequently the exhaust gases mass flow rate will be reduced due to the improved brake thermal efficiency. The load fraction of the DFE will be lower than that of the DE. Therefore, the exhaust gases energy and exergy ratios will be higher for DFE compared with the DE ratios as shown in Figure 11. As the hydrogen substitution percent increases, the DFE load fraction will be decreased compared with DE load and the exhaust gases exergy ratio will be increased. The exhaust gases exergy ratio ranges from $11.2 \%$ to $13 \%$ for the DE and DFE with $40 \%$ hydrogen substitution percent, respectively.

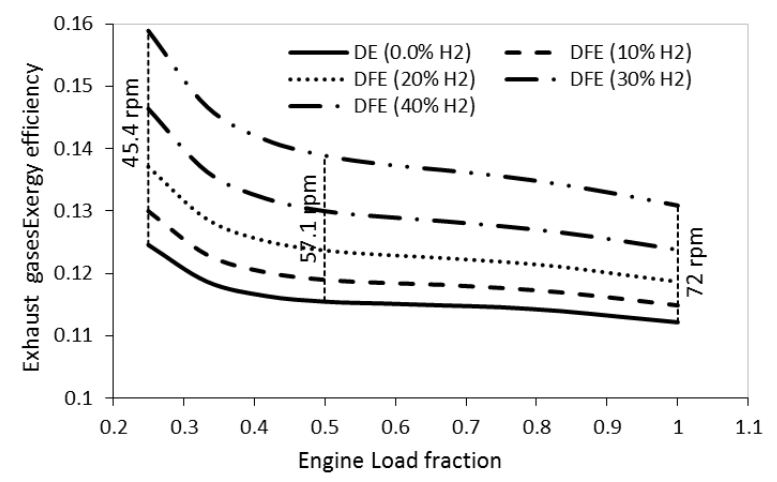

Figure 11 Effect of engine load on the exhaust gases exergy ratio using different hydrogen percentages

\subsection{Environmental analysis results}

The effects of using different hydrogen energy contents in diesel-hydrogen dual fuel engine are analyzed to evaluate its influence on the exhaust gas pollutants. Hydrogen gas has higher flame speed propagation than that of diesel fuel $[50,51]$. Therefore, substitution of diesel fuel with hydrogen gas in DFE will enhance the premixing of the combustible mixtures due to the increased hydrogen to carbon ratio $(\mathrm{H} / \mathrm{C})$. This will increase the combustion efficiency. The higher the combustion efficiency, the lower carbon monoxide ( $\mathrm{CO})$ and carbon dioxide $\left(\mathrm{CO}_{2}\right)$ emissions will be produced which agrees with the published researches [52-55]. Figure 18 shows the relative change in DFE emissions compared with DE at different hydrogen percentages. The specific $\mathrm{CO}_{2}$ emissions are reduced from $588.8 \mathrm{~g} / \mathrm{kWhr}(\mathrm{DE})$ to 482.0 $\mathrm{g} / \mathrm{kWhr}, 398.7 \mathrm{~g} / \mathrm{kWhr}, 288.5 \mathrm{~g} / \mathrm{kWhr}$, and $224.6 \mathrm{~g} / \mathrm{kWhr}$ for the DFE with hydrogen percentages of $10 \%, 20 \%, 30 \%$, and $40 \%$, respectively. This is equivalent to the reduction percentages of $18.2 \%, 32.3 \%, 51.0 \%$, and $61.8 \%$, respectively. In addition, $\mathrm{CO}$ emissions will be reduced by $57.3 \%, 62.6 \%, 67.0 \%, 68.3 \%$, respectively. On the other hand, hydrogen gas increases the probability of the complete combustion in DFE. This will lead to higher incylinder temperature and peak pressure [56-60]. $\mathrm{NO}_{\mathrm{x}}$ emission formation depends on the oxygen concentration, reaction duration and the in-cylindrical temperature rise $[55,61]$. As a result of the increased incylinder temperature, $\mathrm{NO}_{\mathrm{x}}$ emissions will be increased with the hydrogen enrichment percentages and this agrees with the pervious literature [52-54]. Figure 12 shows the increased $\mathrm{NO}_{\mathrm{x}}$ emissions from $17.0 \mathrm{~g} / \mathrm{kWhr}$ to $36.8 \mathrm{~g} / \mathrm{kWhr}, 37.7 \mathrm{~g} / \mathrm{kWhr}, 45.0 \mathrm{~g} / \mathrm{kWhr}$, and $55.1 \mathrm{~g} / \mathrm{kWhr}$ for the DFE with hydrogen percentages of $10 \%, 20 \%, 30 \%$, and $40 \%$, respectively. The percentages of this increase are $117 \%, 121 \%, 165 \%$, and $223 \%$, respectively compared the pure diesel engine. 


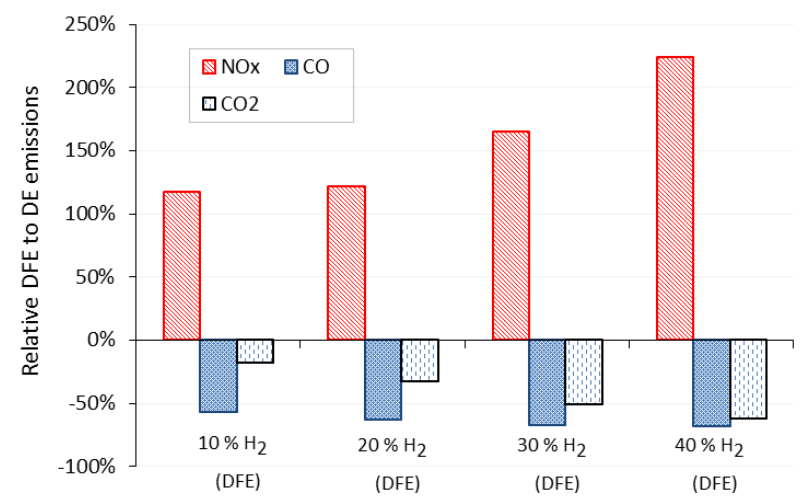

Figure $12 \mathrm{NO}_{\mathrm{x}}, \mathrm{CO}$, and $\mathrm{CO}_{2}$ emissions from DFE compared with pure diesel engine

From Figure 12, it can be noticed that $\mathrm{NO}_{\mathrm{x}}$ emissions will be increased for the DFE. In order to comply with the international maritime organization (IMO) regulations, $\mathrm{NO}_{\mathrm{x}}$ emission rates should be compared with IMO Tier III limits for the year $2016[5,62,63]$. DE and DFE $\mathrm{NO}_{x}$ emission rates can be calculated using the emission factors for the slow speed diesel engine operated with ultra-low sulfur fuel $(0.1 \% \mathrm{~S})$ [49] and DFE emission rates as a function of hydrogen percentages expressed in Eq. 22. These rates should be checked with the required IMO limits. Figure 13 illustrates the different $\mathrm{NO}_{\mathrm{x}}$ emission factors for DE and DFE using different hydrogen percentages. The rate of NOx emissions increased from $9.06 \mathrm{~kg} / \mathrm{min}$ for the case study DE to $19.66 \mathrm{~kg} / \mathrm{min}, 20.07$ $\mathrm{kg} / \mathrm{min}, 24.01 \mathrm{~kg} / \mathrm{min}$, and $29.32 \mathrm{~kg} / \mathrm{min}$ for DFE using input hydrogen energy percentages of $10 \%, 20 \%, 30 \%$, and $40 \%$, respectively. These rates reveals that $\mathrm{NO}_{\mathrm{x}}$ emission rates for both DE and DFE (10\% hydrogen) are higher than that of IMO limits by $344.3 \%$ and $864.2 \%$, respectively. Therefore, these rates should be decreased to comply with the required IMO regulation for $\mathrm{NO}_{\mathrm{x}}$ emissions Tier III.

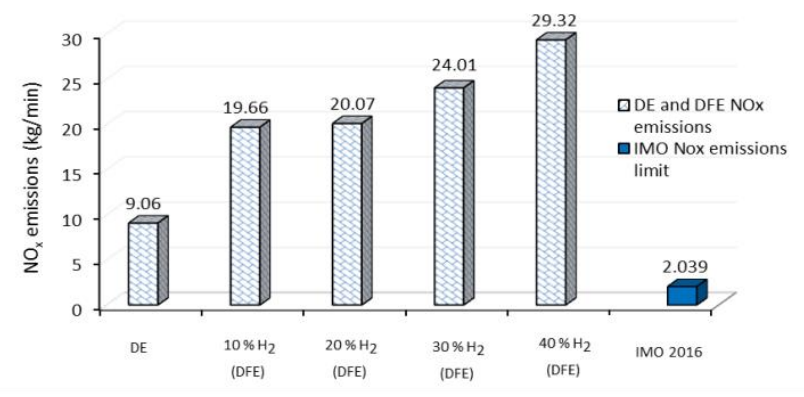

Figure 13 Effect of hydrogen substitution percentages on $\mathrm{NO}_{\mathrm{x}}$ emissions compared with IMO limits

Two methods can be used to reduce $\mathrm{NO}_{\mathrm{x}}$ emissions from marine diesel engines either using after treatment devices or engine modifications. Engine modifications includes direct water injection, EGR (exhaust gas recirculation), and humid air motors [64]. Selective Catalytic Reduction (SCR) is the most common after- treatment device. It uses urea or ammonia with a specific catalyst to reduce $\mathrm{NO}_{x}$ emissions by $90 \%[\underline{5}, \underline{65}, \underline{66}]$. The use of SCR system will reduce $\mathrm{DE} \mathrm{NO}$ emissions to 1.9 $\mathrm{kg} / \mathrm{min}$ and DFE to $2.007 \mathrm{~kg} / \mathrm{min}, 2.401 \mathrm{~kg} / \mathrm{min}$, and 2.932 $\mathrm{kg} / \mathrm{min}$ using hydrogen percentages of $10 \%, 20 \%, 30 \%$, and $40 \%$, respectively. Figure 14 shows the relative $\mathrm{NO}_{\mathrm{x}}$ emission reduction percentages compared with IMO Tier III limits. DFE with hydrogen percentages of $10 \%$ and $20 \%$ would comply with the $\mathrm{IMO} \mathrm{NO}$ regulations with relative percentages of $96.4 \%$ and $98.4 \%$, respectively after using SCR system.

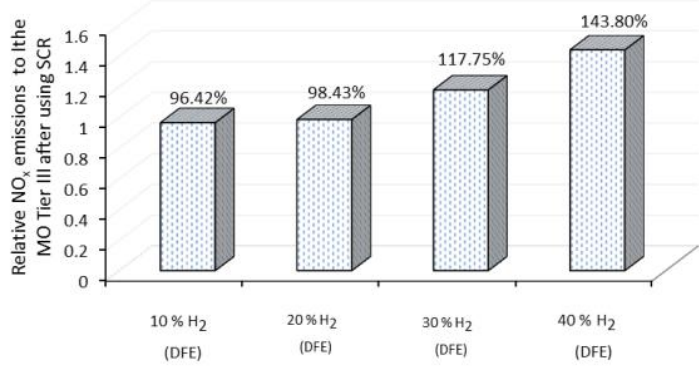

Figure 14 The relative $\mathrm{NO}_{\mathrm{x}}$ emission reduction to IMO Tier III using SCR after treatment method

\section{Conclusions}

The energetic, exergetic, and environmental analysis of a two stroke marine diesel engine were studied using diesel-hydrogen dual fuels at different engine loads with various input hydrogen fractions. The main conclusions from the case study can be summarized as follows:

- From an energy point of view, the brake thermal efficiency of the dual fuel engine increased from $50 \%$ for the pure diesel fuel to $52.0 \%, 53.1 \%, 56.2 \%$, and $58.0 \%$ using input hydrogen energy fractions of $10 \%$, $20 \%, 30 \%$, and $40 \%$, respectively. The exhaust gases temperature for the dual fuel engine are reduced due to the improved combustion efficiency of the dual fuels. As the input hydrogen energy fraction increase, the energy lost in the exhaust gases and cooling water decrease as a result of the reduction in the specific fuel consumption and the improved thermal efficiency of the dual fuel engine.

- From an exergy point of view, the exergetic efficiency and sustainability index values are increased by $21.7 \%$ and $22.9 \%$, respectively for the dual fuel engine (DFE) with $40 \%$ input hydrogen energy fraction compared with pure diesel engine. This increase in exergy is due to the reduced destruction exergy of the diesel engine (DE) from $39 \%$ to $27.6 \%$ for the DFE with $40 \%$ hydrogen, respectively and the increased mechanical shaft exergy from $46.2 \%$ for the diesel engine to $56.3 \%$ for the DFE with $40 \%$ input hydrogen energy. In addition, the exergy ratio of the exhaust gases from the input exergy are increased from $11.2 \%$ for the DE to $11.5 \%, 11.9 \%$, 
$12.4 \%$, and $13.1 \%$ for the DFE with input hydrogen energy percentages of $10 \%, 20 \%, 30 \%$, and $40 \%$, respectively. Conversely, the cooling water exergy ratio is reduced from $3.5 \%$ for the DE to $3 \%$ for the DFE (40\% hydrogen).

- From an environmental point of view, the reduction percentages in $\mathrm{CO}$ and $\mathrm{CO}_{2}$ emissions for the DFE, with $40 \%$ input hydrogen energy, are $68.3 \%$ and $61.8 \%$, respectively. In addition, the percentages of the increase in DFE- $\mathrm{NO}_{\mathrm{x}}$ emissions are $117 \%, 121 \%$, $165 \%$, and $223 \%$ for the input hydrogen energy percentages of $10 \%, 20 \%, 30 \%$, and $40 \%$, respectively, compared the pure diesel engine. Selective catalytic reduction method can be used to reduce $\mathrm{NO}_{\mathrm{x}}$ emissions by $90 \%$. After this reduction, DFE with input hydrogen percentages of $10 \%$ and $20 \%$ would comply with the required international $\mathrm{NO}_{\mathrm{x}}$ regulations with relative percentages of $96.4 \%$ and $98.4 \%$, respectively.

\section{Acknowledgments}

The author is grateful to Hyundai-MAN B\&W Company for the main engine shop test results. Also, many thanks are due to the technical manager of Al Dhail container ship.

\section{References}

[1] Ammar, N.R. and A.I. Farag, CFD Modeling of Syngas Combustion and Emissions for Marine Gas Turbine Applications. Polish Maritime Research, 2016. 23 (3)(3): p. 39-49.

[2] Ammar, N.R. and N.F.S.H. Alshammari, Overview of the Green Hydrogen Applications in Marine Power Plants Onboard Ships. International Journal of Multidisciplinary and Current Research (IJMCR), 2018. 6: p. 84-89.

[3] Ammar, N.R. and I.S. Seddiek, Thermodynamic, environmental and economic analysis of absorption air conditioning unit for emissions reduction onboard passenger ships. Transportation Research Part D: Transport and Environment, 2018. 62: p. 726-738.

[4] Ammar, N.R., Energy- and cost-efficiency analysis of greenhouse gas emission reduction using slow steaming of ships: case study RORO cargo vessel. Ships and Offshore Structures, 2018. 13(8): p. 868876.

[5] Ammar, N.R. and I.S. Seddiek, Eco-environmental analysis of ship emission control methods: Case study RO-RO cargo vessel. Ocean Engineering, 2017. 137: p. 166 - 173.

[6] Höök, M. and X. Tang, Depletion of fossil fuels and anthropogenic climate change-A review. Energy Policy, 2013. 52: p. 797-809.

[7] Balmaceda, M.M., Differentiation, materiality, and power: Towards a political economy of fossil fuels. Energy Research \& Social Science, 2018. 39: p. 130-140.

[8] Georgiopoulou, M. and G. Lyberatos, Life cycle assessment of the use of alternative fuels in cement kilns: A case study. Journal of Environmental Management, 2018. 216: p. 224-234.

[9] Othman, M.F., et al., Green fuel as alternative fuel for diesel engine: A review. Renewable and Sustainable Energy Reviews, 2017. 80: p. 694-709.

[10]Bae, C. and J. Kim, Alternative fuels for internal combustion engines. Proceedings of the Combustion Institute, 2017. 36(3): p. 3389-3413.
[11]Bicer, Y. and I. Dincer, Clean fuel options with hydrogen for sea transportation: A life cycle approach. International Journal of Hydrogen Energy, 2018. 43(2): p. 1179-1193.

[12] Venkata Sundar Rao, K., S.N. Kurbet, and V.V. Kuppast, A Review on Performance of the IC Engine Using Alternative Fuels. Materials Today: Proceedings, 2018. 5(1, Part 1): p. 1989-1996.

[13]Verhelst, S. and T. Wallner, Hydrogen-fueled internal combustion engines. Progress in Energy and Combustion Science, 2009. 35(6): p. 490-527.

[14]Rakopoulos, C.D., et al., Availability analysis of hydrogen/natural gas blends combustion in internal combustion engines. Energy, 2008. 33(2): p. 248-255.

[15]Tsujimura, T. and Y. Suzuki, The utilization of hydrogen in hydrogen/diesel dual fuel engine. International Journal of Hydrogen Energy, 2017. 42(19): p. 14019-14029.

[16]Sharma, P. and A. Dhar, Compression ratio influence on combustion and emissions characteristic of hydrogen diesel dual fuel $\mathrm{Cl}$ engine: Numerical Study. Fuel, 2018. 222: p. 852-858.

[17] Haragopala Rao, B., K.N. Shrivastava, and H.N. Bhakta, Hydrogen for dual fuel engine operation. International Journal of Hydrogen Energy, 1983. 8(5): p. 381-384.

[18] Li, H. and G.A. Karim, Knock in spark ignition hydrogen engines. International Journal of Hydrogen Energy, 2004. 29(8): p. 859-865.

[19] Lee, J.T., et al., An Investigation of a Cause of Backfire and Its Control Due to Crevice Volumes in a Hydrogen Fueled Engine. Journal of Engineering for Gas Turbines and Power, 2000. 123(1): p. 204-210.

[20]Pan, H., et al., Effect of hydrogen addition on criteria and greenhouse gas emissions for a marine diesel engine. International Journal of Hydrogen Energy, 2014. 39(21): p. 11336-11345.

[21] Hosseini, S.M. and R. Ahmadi, Performance and emissions characteristics in the combustion of co-fuel diesel-hydrogen in a heavy duty engine. Applied Energy, 2017. 205: p. 911-925.

[22] Deb, M., et al., An experimental study on combustion, performance and emission analysis of a single cylinder, 4-stroke DIdiesel engine using hydrogen in dual fuel mode of operation. International Journal of Hydrogen Energy, 2015. 40(27): p. 85868598.

[23] de Morais, A.M., et al., Hydrogen impacts on performance and $\mathrm{CO} 2$ emissions from a diesel power generator. International Journal of Hydrogen Energy, 2013. 38(16): p. 6857-6864.

[24]Kumar, A., et al., Synthesis of cobalt hexacyanoferrate nanoparticles and its hydrogen storage properties. International Journal of Hydrogen Energy, 2018. 43(16): p. 7998-8006.

[25]Huanjian, W., et al., Catalytic effect of graphene on the hydrogen storage properties of Mg-Li alloy. Materials Chemistry and Physics, 2018. 207: p. 221-225.

[26]Varde, K.S. and G.A. Frame, Hydrogen aspiration in a direct injection type diesel engine-its effects on smoke and other engine performance parameters. International Journal of Hydrogen Energy, 1983. 8(7): p. 549-555.

[27] Ghazal, O.H., Performance and combustion characteristic of $\mathrm{Cl}$ engine fueled with hydrogen enriched diesel. International Journal of Hydrogen Energy, 2013. 38(35): p. 15469-15476.

[28]Nguyen, T.A. and M. Mikami, Effect of hydrogen addition to intake air on combustion noise from a diesel engine. International Journal of Hydrogen Energy, 2013. 38(10): p. 4153-4162.

[29] Lata, D.B., A. Misra, and S. Medhekar, Effect of hydrogen and LPG addition on the efficiency and emissions of a dual fuel diesel engine. International Journal of Hydrogen Energy, 2012. 37(7): $p$ 6084-6096.

[30]Tomita E., et al. Hydrogen combustion and exhaust emissions ignited with diesel oil in a dual fuel engine. SAE Technical Paper 2001-01-3503. 2001; Available from: https://www.sae.org/ publications/technical-papers/content/2001-01-3503/.

[31]Roy, M.M., et al., An experimental investigation on engine performance and emissions of a supercharged $\mathrm{H} 2$-diesel dual-fuel engine. International Journal of Hydrogen Energy, 2010. 35(2): p. 844-853. 
[32]Zhang, Z., et al., Numerical study of exhaust reforming characteristics on hydrogen production for a marine engine fueled with LNG. Applied Thermal Engineering, 2017. 124: p. 241-249.

[33] Veldhuis, I.J.S., R.N. Richardson, and H.B.J. Stone, Hydrogen fuel in a marine environment. International Journal of Hydrogen Energy, 2007. 32(13): p. 2553-2566.

[34] Chen, L., T.L. Yip, and J. Mou, Provision of Emission Control Area and the impact on shipping route choice and ship emissions. Transportation Research Part D: Transport and Environment, 2018. 58: p. 280-291.

[35]Styhre, L., et al., Greenhouse gas emissions from ships in ports Case studies in four continents. Transportation Research Part D: Transport and Environment, 2017. 54: p. 212-224.

[36]Moran, M.J., et al., Fundamentals of engineering thermodynamics. eighth edition. 2014: John Wiley and Sons.

[37]Caliskan, H., A. Hepbasli, and I. Dincer, Exergy Analysis and Sustainability Assessment of a Solar-Ground Based Heat Pump With Thermal Energy Storage. Journal of Solar Energy Engineering, 2011. 133(1): p. 011005-011005-8

[38]Rosen, M.A., I. Dincer, and M. Kanoglu, Role of exergy in increasing efficiency and sustainability and reducing environmental impact. Energy Policy, 2008. 36(1): p. 128-137.

[39]Aghbashlo, M., et al., Effect of an emission-reducing soluble hybrid nanocatalyst in diesel/biodiesel blends on exergetic performance of a DI diesel engine. Renewable Energy, 2016. 93: $p$. 353-368.

[40]Shamshirband, S., et al., Support vector machine-based exergetic modelling of a DI diesel engine running on biodiesel-diese blends containing expanded polystyrene. Applied Thermal Engineering, 2016. 94: p. 727-747.

[41] López, I., et al., Effect of the use of olive-pomace oi biodiesel/diesel fuel blends in a compression ignition engine: Preliminary exergy analysis. Energy Conversion and Management, 2014. 85: p. 227-233.

[42] Taghavifar, H., et al., Numerical energetic and exergetic analysis of $\mathrm{Cl}$ diesel engine performance for different fuels of hydrogen, dimethyl ether, and diesel under various engine speeds. International Journal of Hydrogen Energy, 2014. 39(17): p. 9515 9526.

[43]Özkan, M., A Comparative Study on Energy and Exergy Analyses of a $\mathrm{Cl}$ Engine Performed with Different Multiple Injection Strategies at Part Load: Effect of Injection Pressure. Entropy, 2015. 17: p. 244263.

[44] Özcan, H. and M.S. Söylemez, Thermal balance of a LPG fuelled, four stroke SI engine with water addition. Energy Conversion and Management, 2006. 47(5): p. 570-581.

[45]Song, G., et al., Exergy evaluation of biomass steam gasification via interconnected fluidized beds. International Journal of Energy Research, 2013. 37(14): p. 1743-1751.

[46] Çengel, Y.A. and A.J. Ghajar, Heat and Mass Transfer: Fundamentals \& Applications. fourth ed. 2011: McGraw-Hill.

[47] Sughayyer, M., Effects of Hydrogen Addition on Power and Emissions Outputs from Diesel Engines. Journal of Power and Energy Engineering, 2016. 4: p. 47-56.

[48]Abedin, M.J., et al., Energy balance of internal combustion engines using alternative fuels. Renewable and Sustainable Energy Reviews, 2013. 26: p. 20-33.

[49]ICF. Current methodologies in preparing mobile source portrelated emission inventories. 2009; 50-60].
[50]White, C.M., R.R. Steeper, and A.E. Lutz, The hydrogen-fueled internal combustion engine: a technical review. International Journal of Hydrogen Energy, 2006. 31(10): p. 1292-1305.

[51]Boretti, A., Advances in hydrogen compression ignition internal combustion engines. International Journal of Hydrogen Energy, 2011. 36(19): p. 12601-12606.

[52]Zhou, J., et al., A memristor-based architecture combining memory and image processing. Science China Information Sciences, 2014. 57(5): p. 1-12.

[53]Bari, S. and M. Mohammad Esmaeil, Effect of $\mathrm{H} 2 / \mathrm{O} 2$ addition in increasing the thermal efficiency of a diesel engine. Fuel, 2010. 89(2): p. 378-383.

[54]Bose, P.K. and D. Maji, An experimental investigation on engine performance and emissions of a single cylinder diesel engine using hydrogen as inducted fuel and diesel as injected fuel with exhaust gas recirculation. International Journal of Hydrogen Energy, 2009. 34(11): p. 4847-4854.

[55] Köse, H. and M. Ciniviz, An experimental investigation of effect on diesel engine performance and exhaust emissions of addition at dual fuel mode of hydrogen. Fuel Processing Technology, 2013. 114: p. 26-34.

[56]Shin, B., et al., Hydrogen effects on NOx emissions and brake thermal efficiency in a diesel engine under low-temperature and heavy-EGR conditions. International Journal of Hydrogen Energy, 2011. 36(10): p. 6281-6291.

[57]Verhelst, S., et al., Laminar and unstable burning velocities and Markstein lengths of hydrogen-air mixtures at engine-like conditions. Proceedings of the Combustion Institute, 2005. 30(1): p. 209-216.

[58] Jafarmadar, S., Exergy analysis of hydrogen/diesel combustion in a dual fuel engine using three-dimensional model. International Journal of Hydrogen Energy, 2014. 39(17): p. 9505-9514.

[59]Sandalcl, T. and Y. Karagöz, Experimental investigation of the combustion characteristics, emissions and performance of hydrogen port fuel injection in a diesel engine. International Journal of Hydrogen Energy, 2014. 39(32): p. 18480-18489.

[60]Karagöz, Y., et al., Engine performance and emission effects of diesel burns enriched by hydrogen on different engine loads. International Journal of Hydrogen Energy, 2015. 40(20): p. 67026713.

[61] Saravanan, N., et al., Experimental investigation of hydrogen port fuel injection in $\mathrm{DI}$ diesel engine. International Journal of Hydrogen Energy, 2007. 32(16): p. 4071-4080.

[62]Aksoyoglu, S., U. Baltensperger, and A.S.H. Prevot, Contribution of ship emissions to the concentration and deposition of air pollutants in Europe. Atmospheric Chemistry and Physics, 2016. 16(4): p. 1895-1906.

[63] Welaya, Y.M.A., M. Mosleh, and N.R. Ammar, Thermodynamic Analysis of a Combined Solid Oxide Fuel Cell with a Steam Turbine Power Plant for Marine Applications. Brodogradnja, 2014. 65(1): p 97-116.

[64]Burgard, D.A. and C.R.M. Bria, Bridge-based sensing of $\mathrm{NO}_{\mathrm{x}}$ and $\mathrm{SO}_{2}$ emissions from ocean-going ships. Atmospheric Environment, 2016. 136: p. 54-60.

[65]Wik, C., Reducing medium-speed engine emissions. Journal of Marine Engineering and Technology, 2010. A17(A17): p. 37-44.

[66] Feng, L.Y., et al., Decreasing $\mathrm{NO}_{x}$ of a low-speed two-stroke marine Diesel engine by using in-cylinder emission control measures. Energies, 2016. 9: p. 304. 